\section{Institutional Tuition Fee Discounts: Cost Sharing Without Loans}

\section{Arthur M. Hauptman}

Arthur M. Hauptman is a public policy consultant, based in Arlington, Virginia, specializing in higher education finance issues. E-mail: hauptman_a@yahoo.com.

$\mathbf{T}^{\mathrm{n}}$ developed and developing countries around the world, one 1 of the most hotly debated higher education topics is whether to increase cost sharing by instituting or raising the tuition fees charged at public institutions. A common argument made by advocates of greater cost sharing is that higher tuition fees increase the resources to improve the quality and scope of the enterprise, including providing more access by adding more seats. Another argument for greater cost sharing is that higher fees can introduce greater equity into the system by having students pay amounts closer to their and their families' abilities to pay for higher education. A third argument is that higher fees will more nearly reflect the private benefits that college students are likely to receive in the form of higher incomes throughout their lifetime

However, all of these arguments for greater cost sharing depend critically on more student aid being provided to help those students and families who cannot afford to pay the higher fees. More student aid is the only means by which access and equity objectives can be advanced through higher fees. Put another way, without sufficient student aid, higher tuition fees will reduce the demand for higher education, especially among students from lower-income families, who will have the most difficulty paying the higher fees.

\section{The Downside of Student Loans}

But what kinds of student aid are best for offsetting the negative effects of greater cost sharing? Most frequently, student loans are presented as the way to ameliorate the demandreducing effects of higher fees and to advance the goals of greater access and equity.

To be clear, there is no doubt that the ready availability of student loans is an effective and intellectually defensible way to help students and their families meet the higher costs entailed in any cost-sharing arrangement. Loans are also theoretically and practically the best way to help students pay for the higher lifetime incomes they are likely to receive because then students are borrowing to pay for their investment in themselves. But it should be noted that a number of factors may limit the effectiveness of student loans in helping to pay for an aggressive cost-sharing scheme.
First, many countries lack the infrastructure to ensure adequate levels of repayment of student loans. To be cost-effective and fair, a student loan program needs a reasonable chance of collecting repayment of most loans that are provided. This task requires either a viable private banking structure with a tradition of making consumer loans or a government tax structure with high levels of compliance. Most developing countries and a number of developed ones lack either of these repayment structures.

Second, student loan programs typically take a long time to develop and mature. They require a complex administrative structure that includes the development of promissory notes, servicing procedures, and collection systems that take at least several years to develop. If student loans are linked to cost sharing, the maturation process required for student loans can postpone the implementation of effective cost-sharing arrangements.

In addition, the international experience is that student loan programs (and government-funded student aid programs in general) often lead to the creation of a number of questionable academic and training programs established largely for the purpose of capturing student aid funds. These programs often have very high student loan default rates that further erode the credibility of both student aid and cost sharing.

Carlo Salerno in the most recent IHE issue enumerates these concerns with student loans ("Cost Sharing in Higher Education Financing: Economic Perils in Developing Countries," IHE, no. 43, Spring 2006). He goes on to say that these very real problems with student loans limit the viability of cost sharing in developing countries by increasing the likelihood that higher fees will discourage equity, hinder overall economic growth, and diminish quality (through the expansion of questionable academic and training programs).

More student aid is the only means by which access and equity objectives can be advanced through higher fees.

The Benefits of Tuition Fee Discounts

But the problems of reliance on student loans as a financing mechanism for higher fees can be largely avoided if institutional tuition fee discounts are used as the primary vehicle for financing cost sharing. Tuition fee discounts occur when educational institutions do not collect some or all of the fees they nominally charge their students. These discounts are limited to certain groups of students, based on financial need, academic merit-or other criteria such as athletic prowess, musical ability, and other admirable student characteristics that the institution wishes to reward by charging lower or no fees.

Such a system of tuition waivers has much to recommend it. It is much simpler to administer than a student loan pro- 
gram, and it can be implemented much more quickly. A system of waivers can be established at the same time that fees are increased, whereas student loan programs will normally take at least several years to develop.

Moreover, using tuition fee discounts to address the equity concerns attached to cost sharing still allows for more resources to come into the system. It is the case that the more students who receive discounts and the bigger discounts they receive, the fewer resources will be generated. However, even if only one-quarter of students are identified as those who can afford to pay the higher fees, institutional revenues will still be

\section{But the problems of reliance on student loans as a financing mechanism for higher fees can be largely avoided if institutional tuition fee discounts are used as the primary vehicle for financing cost shar- ing.}

increased by that amount without any of the negative consequences of loan defaults and administrative complexities. A higher proportion of fee-paying students will generate that much more in resources for the system.

What makes for an effective tuition-fee discount program? The key is that the discounts are targeted on students who are truly unable to pay the higher fees or whose academic records qualify them for merit-based assistance in the form of a discount. The temptation will be strong, though, for institutions to minimize the number of students who receive the discount or to use discounts as a marketing device to attract high-achieving but less needy students through lower prices. Either of these institutional practices will defeat the policy incentive of using higher fees to work to resolve equity concerns.

\section{The Role of Govern ment}

This is where the government has a role to play-actually, two roles: first, to develop standards that help identify those students who should qualify for the discount; and second, to help ensure that targeted groups of students actually get the discount by reimbursing institutions only for the discounts provided to groups of students designated by the government as truly needy or meritorious enough to qualify for the aid.

The government's obligation includes developing a process that will identify the students who qualify for the waiver in a way that is fair to both students and taxpayers. This raises questions about what kind of means test might be used to identify students who qualify as needy_as a general rule, the simpler the process for identifying needy students the better. In countries where income is not readily available or reliable, other easily auditable measures could be used, such as whether the student goes to a school with high concentrations of poor students or whether the family owns a car, lives in a house with indoor plumbing.

The government also must implement a process that ensures institutions will be willing to enroll the students whom the government or other bodies have determined as qualifying for the waiver. The concern here is that institutions will not admit students for whom a large discount is required-they will be more inclined to admit students who will pay the full fee or at least most of it. This concern can be addressed by the government providing aid funds to institutions to replace the fees that have been waived for targeted students.

Is there a role for student loans in such a system of fee discount? Yes, especially in meeting the cash flow needs of middle- and upper-income students whose families may have the assets but not the immediate means to pay the higher fees. But the loan system can be introduced later; it need not be in place for the greater cost sharing to commence.

While student loans can certainly be an important component in paving the way for higher fees and greater cost sharing, they are not a necessary condition. What is necessary is a process by which institutions waive the higher fees for students who truly cannot afford them. Such a fee waiver system can help policymakers achieve a number of key access and quality objectives and can provide a safety net to protect needy students. Tuition fee discounts become the means for ensuring equity objectives while enhanced cost-sharing strategies are being utilized to increase the resources coming into the system.

\section{Education and Employment Among Women in the UAE}

\section{Fatma Abdulla}

Fatma Abdulla is dean at the Sharjah Higher Colleges of Technology. Address: Sharjah Higher Colleges of Technology, P.O Box 7947, Sharjah, United Arab Emirates. E-mail: fatma.abdulla@hct.ac.ae.

Three of every five students in public higher education in the 1 United Arab Emirates are women. The vast majority $(80$ percent) of these young women are first-generation college students. Their fathers are more likely to have higher educational levels than their mothers, because Emirati men had access to education and diverse employment opportunities well before their female counterparts. The first school for men was established in the early I950s, while women's schools opened their doors almost a decade later. Despite their late start, women have made monumental strides at all levels of the education system because of two factors. The first is the presence of 